\title{
Equity Returns and Volatilities Before and After the 2007-08 Financial Crisis
}

\author{
Lidija Dedi * \\ Burhan Faith Yavas ***
}

\begin{abstract}
This paper investigates the linkages among equity markets of four European countries (Germany, France, Italy, UK) and the USA in terms of market returns and transmission of volatilities. We use daily exchange traded funds (ETF) data from January 2002 to March 2016 and utilize both a Multivariate Autoregressive Moving Average model (MARMA) and a Generalized Autoregressive Conditional Heteroskedasticity model (GARCH). We divided the data into three separate periods: before the 2007-08 financial crisis, during the crisis and after the crisis. The results show the existence of significant co-movement of returns in all three selected periods although some important differences before and after the financial crisis are noted. Findings also include marked increases in integration of the markets and thus diminishing diversification opportunities for investors. Volatilities appear to react strongly to market movements and their shocks fade away slowly in all five countries during the crisis period. There is also strong evidence of volatility spillovers particularly during and after the crisis periods.
\end{abstract}

Keywords: co-movement of returns; volatility persistence; volatility spillovers; GARCH; Exchange traded funds

JEL Classification: G11, G15, C58

\section{Introduction}

Markets across the world experience a growing foreign presence. Investors, heeding the advise of money managers not to put all of their eggs in one basket have moved part of their portfolios to countries other than their own, The Wall Street Journal reports that about 20 percent of US nonfinancial shares were held by overseas inves-

\footnotetext{
* Lidija Dedi is at University of Zagreb, Faculty of Economics and Business, Zagreb, Croatia.

** Burhan Faith Yavas is at California State University Dominguez Hills, CA, USA.
} 
tors (in 2015) compared to about 10 percent in 2000 (WSJ-March 28, 2016). Similar trends are observed in the UK (54\% foreign ownership in 2014), in Germany (64\%) and Japan (32\%). Increased foreign presence in equity markets globally may not be the only reason why they tend to move together in recent years. Since the 1980s, more and more money was flowing across borders; capital markets were becoming increasingly integrated. However, there is evidence that since the 2007-2008 financial crisis this particular aspect of globalization has slowed. This may partly be a consequence of events in the euro zone, where the sovereign-debt crisis caused banks to cut back their lending to weaker economies. In fact, when financial flows are added, including direct investment, in 2015, cross-border volumes were only half 2007's level (Economist, December 17, 2016). Expectedly, the growth in global integration of financial markets prior to the 2007-08 financial crisis and its slowdown since has given rise to many studies that investigate the mechanism through which equity market movements and volatilities are transmitted around the world. These studies make it clear that while real economic conditions and equity market performances are linked, the performance of equity markets also vary based on international factors, so that market performance is not perfectly correlated across countries (Yavas \& Dedi, 2016). They also indicate that the markets become more closely correlated after unexpected events or shocks (Rezayat \&Yavas, 2006; Gray, 2009). From investors' perspective, a better understanding of how markets move together may result in superior portfolio construction and hedging strategies, while helping policy makers (especially central banks) gain an understanding of the processes and consequences of such spillovers. In other words, sheding more light on the information transmission process among equity markets is important for both micro (asset valuation and risk management) and macro (economic policy and risk management) agents. If market interrelations and connectedness are not understood, the results could include implementation of inadequate or even counterproductive regulatory policies. Therefore, it is important to understand where volatilities arise from, how and where they are transmitted.

The main motivation in this paper is to explore price and volatility linkages between USA and selected European markets by utilizing broad equity market index based ETFs with the main objective of contributing to the literature on the linkages among international equity markets in different periods of volatility as manifested by the 2007-08 financial crisis. In examining the return co-movements, transmission and persistence of volatilities in county equity markets, we seek to understand both if there are differences in different time periods in terms of return and volatilities and if there are opportunities for international investors/traders to earn a better return for a unit of risk. Since the ETFs used in this study are all equity ETFs representing broad equity market indices the paper uses "equity returns" and "ETF returns" interchangeably. 


\section{Literature Review}

Much of the earlier research in international stock markets concentrated exclusively on spillover of the co-movement between returns (Bekaert et al., 2009; Kim and Langrin 1996; Rezayat \& Yavas 2006; Yavas \& Rezayat, 2008). These studies found low but increasing correlations across some country equity markets providing attractive diversification opportunities. Similarly, Gray (2009) found financial contagion among emerging EU countries and their linkages strengthen after the 2007 crisis.

More recent research (e.g. Dedi \& Yavas, 2016; Diebold \& Yilmaz, 2011; Kumar, 2013; Rey, 2013) demonstrated that more information is revealed in the volatility of stock prices. Henceforth, studying the transmission of stock market movements became a joint study of the spillover of prices as well as the volatility of prices. The interest in volatilities has also increased after the two recent stock market crashes (dot.com of 2000 and financial crisis of 2007-2008) which witnessed wide swings in asset prices. However, academic research on equity market volatility transmission has not been conclusive. For example, focusing on emerging markets, Scheicher (2001) indicated that equity markets' return co-movements were significant but not their volatilities. Li (2007) examined the linkages between Shanghai and Shenzhen stock exchanges of China, Hong Kong and the United States, and found no spillovers (return and volatility) between the stock exchanges in China and U.S. markets, although unidirectional volatility spillover from Hong Kong to those in Shanghai and Shenzhen markets was significant. Other studies examining the spillover of information both in terms of return and volatility include Hamao et al. (1990), Christofi \& Pericli (1999), Kumar \& Mukhopadyay (2002). They found intra-regional volatility spillovers to be more significant than the inter-regional spillovers.

Turning next specifically to the literature on financial crises and the market contagion, Kenourgiosa et al. (2011) investigate market co-movements on four emerging and two developed markets during five different financial crises and find significant results confirming the contagion phenomenon. Syllignakis \& Kouretas (2011) also find increasing returns correlation among mainly Central and Eastern European (CEE) emerging markets and the US, Germany, and Russia during financial crises and argue that this result is mainly due to herding behavior in the financial markets. Slimane et al., (2013) find evidence that interrelationship among European markets increased substantially during the period of 2007-08 crisis, pointing to an amplification of spillovers. Interestingly, they find that French and UK markets herded around German market. Dungey \& Martin (2007) study both return and volatility spillovers across different equity and currency markets during the East Asian crisis. Their results show that the volatility spillover effects are relatively larger than return spillovers. Focusing mainly on BRIC's stock markets (Brazil, Russia, India, China), and using M-GARCH model Aloui et al. (2011) show strong evidence of dependence between markets during the financial crisis. Orlowski (2012) studies the proliferation 
of risks in US and European financial markets prior to and during the crisis. His results show important levels of volatility during financial distress and a significant increase of risk in only three markets: Germany, Hungary, and Poland.

The present paper addresses several gaps found in the literature. First, instead of using stock market indices like most of the existing literature, we utilize ETFs in this study. We also use daily data as opposed to the weekly or monthly data used in other studies. While weekly/monthly data can have advantages in terms of limiting "noise" daily data provide a larger number of observations. We study multi-directional flows whereas most of the literature focuses on uni-directional flows. Finally, in addition to the standard GARCH methodology we employ MARMA. The present paper also addresses the questions of "volatility persistence" in addition to "volatility transmission". By dividing the data into three separate time periods, we not only seek to study intermarkets return and volatility spillovers simultaneously, but also investigate the question of how these spillovers are affected by the economic and financial shock to the global equity markets. As such, we test indirectly the hypothesis that financial contagion among the US and the major European markets strengten after the 200708 crisis.

\section{Data and Methodology}

This study utilizes Exchange Traded Funds (ETF) instead of market indices. ETFs are arguably one of the most versatile of financial instruments that invest mostly in corporate and sovereign liabilities with the intension of replicating the returns of a market index. This paper utilizes iShares MSCI Capped/Core Equity ETFs (all Equity ETFs used in this research are issued by iShares). "iShares" is the largest ETF provider in the world. Selected ETFs seek to track the investment results of a particular index. The MSCI Index was created by Morgan Stanley Capital International. Each MSCI Index measures a different aspect of global stock market performance.

We divided the data into three separate periods: a five-year period before the 2008 financial crisis, a period during the crisis and finally, a five years after the crisis. The data period is from January 8, 2002 to March 31, 2014, a sample of 2933 days on the following ETFs: 1. The iShares MSCI United Kingdom ETF (EWU) seeks to track the investment results of an index composed of U.K. equities. 2. The iShares MSCI Germany ETF (EWG) tracks the performance of publicly traded securities in the MSCI Germany market index. 3. The iShares MSCI France Capped ETF (EWQ) seeks to track the investment results of a broad-based index composed of French equities. 4. The iShares MSCI Italy Capped ETF (EWI) seeks to track the investment results of a broad-based index composed of Italian equities. 5. The iShares MSCI USA Core S\&P 500 ETF (IVV) seeks to track the investment results of an index composed of large-capitalization U.S. equities S\&P 500 (BlackRock, 2015). 
By concentrating the analysis on ETF data, we can mitigate if not entirely avoid some substantial problems that arise in traditional academic research such as exchange rates volatility, divergences in the national tax systems, diversities in stock exchange trading times and bank holidays, restrictions on cross-border trading and investments, transaction costs. Designed to mimic the movements of MSCI indices, ETFs provide an easy pool of international diversification products for an investor.

To study co-movements of daily returns, we employed a multivariate autoregressive moving average model (MARMA). To measure the dynamic relationship of the volatility of a process, on the other hand we used generalized autoregressive conditional heteroskedastic (GARCH) models.

\section{Multivariate Autoregressive Moving Average Model (MARMA)}

MARMA models combine some of the characteristics of the univariate autoregressive moving average models and, at the same time, some of the characteristics of regression analysis. A MARMA model deals with an output time series $Y_{t}$, which is presumed to be influenced by a vector of input time series $X_{t}$, and other inputs (factors) collectively grouped and called "noise", $e_{\mathrm{t}}$. The input series $X_{t}$ exerts its influence on the output series via a transfer function, which distributes the impact of $X_{t}$ over several future time periods. The objective of the transfer function modeling is to determine a parsimonious model relating $Y_{t}$, to $X_{t}$, and $\mathrm{e}_{\mathrm{t}}$ (Makridakis et al. 1998). The transfer function model, in general, may be represented as:

$$
j(L) Y_{t}=w(L) X_{t}+q(L) \varepsilon_{t}
$$

where $j(\mathrm{~L}), w(\mathrm{~L}), q(\mathrm{~L})$ are polynomials of different orders in $L$. Polynomial $j(L)=(1$ $\left.-j_{1} L^{1}-j_{2} L^{2}-\ldots-j_{\mathrm{p}} L^{\mathrm{p}}\right)$ represents autoregressive part of order $\mathrm{p}$, " $L$ " denotes lag, $L^{1} Y_{\mathrm{t}}$ represents $Y_{t 1}$, and polynomial $q(L)=\left(1-q_{1} L^{1}-\ldots-q_{\mathrm{p}} L^{\mathrm{q}}\right)$ represents moving average part of order $q$.

\section{Generalized Autoregressive Conditional Heteroskedasticity Model (GARCH)}

To measure the dynamic relationship of the volatility of a process, among the models can be used are exponential smoothing or autoregressive conditional heteroskedastic (ARCH) and generalized autoregressive conditional heteroskedastic (GARCH) models. ARCH models were introduced by Engle (1982) and generalized as GARCH by Bollerslev (1986). GARCH models, have become widespread tools for dealing with time series heteroskedasticity and are more widely used to model the conditional volatility of financial series. Practically, GARCH models are fitted when errors of AR or ARMA or in general a regression model have variances which are not independent or 
the variance of the current error term is related to the value of the previous periods' error terms as well as past variances. The coefficients of the past periods' squared error terms is an indicative of the strength of the shocks in the short term while the coefficient of the past variances (GARCH effect) measures the contribution of these shocks to long run persistence (Grosvenor \& Greenidge, 2012).

The specification of a typical GARCH model is given by:

$$
\sigma_{t}^{2}=\omega+\beta(L) \sigma_{t-1}^{2}+\alpha(L) \varepsilon_{t}^{2}
$$

and $\varepsilon_{t}^{2} \mid \Psi_{t-1} \sim N\left(0, \sigma_{t-1}^{2}\right)$ is the innovation in the asset returns and $\Psi_{\mathrm{t}-1}=\left\{\mathrm{y}_{\mathrm{t}-1}, \varepsilon_{\mathrm{t}-1,1} \mathrm{y}_{\mathrm{t}-2}\right.$, $\varepsilon_{\mathrm{t}-2} \ldots$ ), where $\mathrm{y}_{\mathrm{t}-\mathrm{i}}$, represents the return at time t-i and $\varepsilon_{\mathrm{i}}$ is the error resulting from a regression or an ARMA model fitted to returns. This is similar to ARMA models where $\beta(L)$ of order $\mathrm{p}$ is the autoregressive term and polynomial $\alpha(L)$ of order $\mathrm{q}$ is the moving average term.

GARCH processes have commonly tails heavier than the normal distribution. This property makes the GARCH process attractive because the distribution of asset returns frequently display tails heavier than the normal distribution. In most empirical applications with finitely sampled data, the simple ARCH (1) or GARCH $(1,1)$ is found to provide a fair description of the data. ARCH (1) model is as follows:

$$
\sigma_{t}^{2}=\omega+\alpha \varepsilon_{t-1}^{2}
$$

And a sufficient condition for the conditional variance to be positive is that the parameters of the model satisfy the following constraints: $\omega>0$ and $\alpha>0$.

GARCH $(1,1)$ model is:

$$
\sigma_{t}^{2}=\omega+\alpha \varepsilon_{t-1}^{2}+\beta \sigma_{t-1}^{2} \quad \omega>0,0<\beta \leq 1,0<\alpha \leq 1, \alpha+\beta \leq 1
$$

$\alpha$ is the coefficient that measures the extent to which a volatility shock today feeds through the next period volatility, while $\alpha+\beta$ is usually considered to be a measure of persistence of volatility shock and it measures the rate at which this effect dies over time. The reader is referred to Engle (1982) and Bollerslev (1986) for additional information on GARCH models.

Note that when $y_{t}$, the rate of return on an asset is not function of a regressors (there is no regression component in the model), then $y_{t}$ is identical to $e_{\mathrm{t}}$ indicating a pure GARCH process. In this study we use GARCH $(1,1)$ to analyze the persistence of conditional volatility of the returns as well as transmission of volatility of returns. Daily ETF returns are calculated by $100 *$ logarithmic difference of daily closing ETF values. $\left.r_{t}=100 * d \log p_{t}\right)$. 


\section{Findings}

\section{Co-movements of Returns}

For each return equation in MARMA model, regressors are the other four ETF returns, its own one-period lagged returns as well as one-period lagged returns of other ETF returns. MARMA is an iterative process that eliminates insignificant variables before the next step. Tables 1, 2 and 3 below summarizes MARMA results.

Table 1: Co-movements of Daily ETF Returns (before crisis period 01/08/2002 08/31/2007)

\begin{tabular}{|c|}
\hline $\begin{array}{l}r_{t(\text { France })}=0.39 r_{t(\text { Italy })}+0.33 r_{t(\text { Germany })}+0.31 r_{t(\text { UK })}+0.13 r_{t-1(\text { USA })}-0.17 r_{t-1(\text { France })}+0.09 r_{t-1(\text { Germany })}+ \\
+0.07 r_{t-1(U K)}+0.04 r_{t(U S A)}+e_{t}\end{array}$ \\
\hline$r_{t(\text { Germany })}=0.68 r_{t(\text { France })}+0.29 r_{t(\text { USA })}+0.31 r_{t(\text { Italy })}-0.17 r_{t-1(\text { Germany })}+0.14 r_{t-1(\text { France })}+e_{t}$ \\
\hline$r_{t(\text { Italy })}=0.46 r_{t(\text { France })}+0.17 r_{t(\text { Germany })}+0.21 r_{t(U K)}-0.10 r_{t-1(\text { USA })}-0.07 r_{t(U S A)}+0.04 r_{t-1(\text { France })}+e_{t}$ \\
\hline$r_{t(U K)}=0.49 r_{t(\text { France })}+0.28 r_{t(\text { Italy })}+0.11 r_{t-1(U S A)}-0.16 r_{t-1(U K)}+0.11 r_{t-1(\text { France })}-0.05 r_{t-1(\text { Germany })}+e_{t}$ \\
\hline$r_{t(\text { USA })}=0.42 r_{t(\text { Germany })}-0.30 r_{t-1(\text { USA })}+0.11_{t-1(\text { Germany })}-0.17 r_{t(\text { Ital })}+0.14 r_{t(\text { France })}+e_{t}$ \\
\hline
\end{tabular}

Table 2: Co-movements of Daily ETF Returns (crisis period 09/04/2007 - 02/27/2009)

\begin{tabular}{|c|}
\hline$r_{t(\text { France })}=0.46 r_{t(\text { Italy })}+0.29 r_{t(\text { UK })}+0.28 r_{t(\text { Germany })}-0.04 r_{t-1(\text { traly })}+0.04 r_{t-1(\text { USA })}+e_{t}$ \\
\hline$r_{t(\text { Germany })}=0.85 r_{t(\text { France })}+0.12 r_{t(U S A)}-0.13 r_{t-1(\text { Germany })}+0.11 r_{t-1(\text { France })}+e_{t}$ \\
\hline$r_{t(\text { Italy })}=0.95 r_{t(\text { France })}+0.14 r_{t-1(\text { France })}-0.05 r_{t(U S A)}-0.10 r_{t-1(U K)}+e_{t}$ \\
\hline$r_{t(U K)}=0.85 r_{t(\text { France })}+0.10 r_{t(U S A)}+0.10 r_{t-1(U S A)}-0.04 r_{t-1(U K)}+e_{t}$ \\
\hline$r_{t(\text { USA })}=0.49 r_{t(\text { Germany })}-0.49 r_{t-1(\text { USA })}+0.44_{t(U K)}+0.15_{t-1(\text { Germany })}-0.26 r_{t(\text { tally })}+e_{t}$ \\
\hline
\end{tabular}


Table 3: Co-movements of Daily ETF Returns (after crisis period 03/02/2009 $03 / 31 / 2014)$

\begin{tabular}{|c|}
\hline$r_{t(\text { France })}=0.55 r_{t(\text { Germany })}+0.28 r_{t(\text { Italy })}+0.20 r_{t(U K)}-0.05 r_{t-1(\text { Germany })}+0.04 r_{t-1(\text { traly })}+e_{t}$ \\
\hline$r_{t(\text { Germany })}=0.82 r_{t(\text { France })}+0.13 r_{t(U K)}+0.07 r_{t(U S A)}+0.04 r_{t-1(\text { USA })}+e_{t}$ \\
\hline$r_{t(\text { Italy })}=1.13 r_{t(\text { France })}-0.04 r_{t-1(U S A)}-0.07 r_{t(U K)}+e_{t}$ \\
\hline$r_{t(U K)}=0.48 r_{t(\text { France })}+0.22 r_{t(\text { Germany })}+0.12 r_{t(U S A)}+0.13 r_{t-1(U S A)}-0.07 r_{t-1(U K)}-0.05 r_{t(\text { Italy })}+e_{t}$ \\
\hline$r_{t(U S A)}=0.21 r_{t(\text { Germany })}-0.34 r_{t-1(U S A)}+0.08_{t-1(\text { Germany })}+0.22_{t(U K)}+0.08 r_{t-1(U K)}+0.12 r_{t(\text { France })}+e_{t}$ \\
\hline
\end{tabular}

The results of the analysis show the existence of significant co-movement of returns among the countries in the sample in all three selected periods. There were also some important differences before and after the financial crisis. In general, the role played by US returns has changed after the crisis in France and Italy compared with the pre-crisis period.

France: Before and after comparisons indicate that the French returns are affected by the returns of all of the other countries in the sample before the crises. However, the US returns no longer appear in the equation after the crisis. This implies that that the French market pre-crisis moved together with the other markets limiting diversification opportunities. In the post-crisis period however, there existed diversification opportunities for US and France based investors.

Germany: While Italian returns affect the returns in Germany before the crisis, along with returns from France and the US, the Italian returns dissappear after the crisis and are replaced by returns from UK. The implication is that while German and British investors would realize diversification benefits per-crisis, such opportunities disappeared after the crisis when both markets started to move together. On the other hand, the opposite occurred with respect to German and Italian investors.

Italy: Returns from France, Germany and UK move in the same direction with the Italian returns before the crisis (with US returns being negatively related). However, the after crisis equation does not include Germany and both US and UK appear with negative signs to indicate movement of opposite direction with Italian returns - implying that the Italian market may provide diversification opportunites for German, American and British investors.

UK: Pre-crisis UK returns move in concert with the returns from the other markets included in this study. The only exception is Germany where one-period lagged returns move in opposite direction with the UK returns. However, German returns become positively related to the UK returns after the crisis. 
USA: Pre-crisis, the only country returns that move in the same direction as the US returns is Germany. Italian returns move in opposite direction. However, both France and UK enter into the equation (along with Germany) after the crisis. Thus, opportunities for diversification by investing in the US market diminish after the crisis.

In general the results indicate that post-crisis markets become more integrated and move in concert. This finding is in line with many of the earlier studies that indicate that markets become more correlated after a crisis.

\section{Volatility Persistence}

Turning to volatilities (Table 4), we observe that the highest volatility (in terms of standard deviation) before the crisis is exhibited by Germany (1.409) and France (1.232). During the crisis the highest volatility is exhibited by France (2.592) and UK (2.578). However, the highest volatility after crisis is exhibited by Italy (2.046) and France (1.779). On the other hand, the USA market has the lowest volatilities of all markets in all periods (before crisis 0.928; during the crisis 2.317; after crisis 1.144).

Table 4: Volatilities (standard deviations)

\begin{tabular}{|l|c|c|c|c|c|}
\hline & FRANCE & GERMANY & ITALY & UK & USA \\
\hline Std. Dev. (pre-crisis) & 1.232 & 1.409 & 1.029 & 1.039 & 0.928 \\
\hline Std. Dev. (crisis) & 2.592 & 2.480 & 2.493 & 2.578 & 2.317 \\
\hline Std. Dev. (post-crisis) & 1.779 & 1.744 & 2.046 & 1.378 & 1.144 \\
\hline
\end{tabular}

To analyze persistence in volatility we used GARCH $(1,1)$ model. As it is shown in table 5, UK has the highest ARCH coefficient (0.075) but on the other hand, has the lowest GARCH coefficient (0.901) indicating strong shocks in the short term but at the same time these strong short term shocks do not contribute to long run volatility persistence. Long term (cumulative) effect of past shocks on returns is measured by the GARCH parameter $\beta$, which usually ranges between 0.85 and 0.98 . In this study, $\beta$ ranges from a low value of 0.901 in UK to 0.942 in the USA. Looking at both $\mathrm{ARCH}$ and GARCH effects, Germany and Italy have the highest $\alpha$ plus $\beta$ values, indicating that the effects of the volatility shocks fade away slowly. 
Table 5: Volatility Persistence (before crisis)

\begin{tabular}{|c|c|c|c|c|c|}
\hline Coefficient & France & Germany & Italy & UK & USA \\
\hline Constant $\left(\alpha_{0}\right)$ & $\begin{array}{l}0.021 \\
(0.01) \\
\end{array}$ & $\begin{array}{l}0.018 \\
(0.01) \\
\end{array}$ & $\begin{array}{l}0.015 \\
(0.02) \\
\end{array}$ & $\begin{array}{l}0.023 \\
(0.00) \\
\end{array}$ & $\begin{array}{l}0.010 \\
(0.00) \\
\end{array}$ \\
\hline $\operatorname{ARCH}(-1)\left(\alpha_{1}\right)$ & $\begin{array}{l}0.072 \\
(0.00)\end{array}$ & $\begin{array}{l}0.061 \\
(0.00)\end{array}$ & $\begin{array}{l}0.056 \\
(0.00)\end{array}$ & $\begin{array}{l}0.075 \\
(0.00)\end{array}$ & $\begin{array}{l}0.041 \\
(0.00) \\
\end{array}$ \\
\hline $\operatorname{GARCH}(-1)\left(\beta_{1}\right)$ & $\begin{array}{l}0.910 \\
(0.00)\end{array}$ & $\begin{array}{l}0.925 \\
(0.00)\end{array}$ & $\begin{array}{l}0.928 \\
(0.00)\end{array}$ & $\begin{array}{l}0.901 \\
(0.00)\end{array}$ & $\begin{array}{l}0.942 \\
(0.00)\end{array}$ \\
\hline$\alpha_{1}+\beta_{1}<1$ & 0.982 & 0.986 & 0.984 & 0.976 & 0.983 \\
\hline AIC & 2.955 & 3.168 & 2.724 & 2.699 & 2.414 \\
\hline SIC & 2.971 & 3.184 & 2.740 & 2.715 & 2.430 \\
\hline $\begin{array}{l}\text { ARCH-LM test } \\
\text { statistic } \\
\text { (Obs*R-squared) }\end{array}$ & 0.105 & 0.053 & 0.000 & 0.058 & 2.487 \\
\hline Prob. Chi-Square(1) & 0.747 & 0.818 & 0.999 & 0.810 & 0.115 \\
\hline
\end{tabular}

During the crisis period, volatilities react strongly to market movements and volatility shocks fade away slowly in all five countries. All five countries have $\alpha+\beta$ values very close to 1.0 (France 0.9996 ; Germany 0.9986; Italy 0.9988; UK 0.9946; USA 0.9929) suggesting a stronger presence of ARCH and GARCH effects.

After the crisis, as it is shown in table 6, USA has the highest ARCH coefficient (.096) but on the other hand, has the lowest GARCH coefficient (0.879) indicating strong shocks in the short term but at the same time these strong short term shocks do not contribute to long run volatility persistence. In this study, the GARCH parameter $\beta$ ranges from a low value of 0.879 in the USA to 0.941 in UK (it was opposite before the crisis). Looking at both ARCH and GARCH effects, UK and France have the highest $\alpha$ plus $\beta$ values, indicating that the effects of the volatility shocks fade away slowly.

Table 6: Volatility Persistence (after crisis)

\begin{tabular}{|l|c|c|c|c|c|}
\hline coefficient & France & Germany & Italy & UK & USA \\
\hline Constant $\left(\alpha_{0}\right)$ & $\begin{array}{l}0.030 \\
(0.00)\end{array}$ & $\begin{array}{c}0.025 \\
(0.00)\end{array}$ & $\begin{array}{c}0.052 \\
(0.03)\end{array}$ & $\begin{array}{c}0.013 \\
(0.06)\end{array}$ & $\begin{array}{c}0.027 \\
(0.01)\end{array}$ \\
\hline ARCH(-1) $\left(\alpha_{1}\right)$ & $\begin{array}{c}0.053 \\
(0.00)\end{array}$ & $\begin{array}{c}0.050 \\
(0.00)\end{array}$ & $\begin{array}{c}0.060 \\
(0.00)\end{array}$ & $\begin{array}{c}0.050 \\
(0.00)\end{array}$ & $\begin{array}{c}0.096 \\
(0.00)\end{array}$ \\
\hline Garch(-1) $\left(\beta_{1}\right)$ & $\begin{array}{c}0.936 \\
(0.000)\end{array}$ & $\begin{array}{c}0.939 \\
(0.000)\end{array}$ & $\begin{array}{c}0.925 \\
(0.000)\end{array}$ & $\begin{array}{c}0.941 \\
(0.000)\end{array}$ & $\begin{array}{c}0.879 \\
(0.000)\end{array}$ \\
\hline$\alpha_{1}+\beta_{1}<1$ & 0.989 & 0.988 & 0.985 & 0.991 & 0.974 \\
\hline AIC & 3.818 & 3.750 & 4.077 & 3.258 & 2.755 \\
\hline SIC & 3.834 & 3.766 & 4.097 & 3.278 & 2.776 \\
\hline $\begin{array}{l}\text { ARCH-LM test statistic } \\
(\text { Obs*R-squared) }\end{array}$ & 0.225 & 0.995 & 1.314 & 0.090 & 7.111 \\
\hline Prob. Chi-Square(1) & 0.635 & 0.319 & 0.252 & 0.764 & 0.008 \\
\hline
\end{tabular}




\section{Volatility Transmission}

To detect transmission of volatility between stock markets, we use the Augmented GARCH model as developed by Duan (1997).

$$
\sigma_{t}^{2}=\omega+\alpha \varepsilon_{t-1}^{2}+\beta \sigma_{t-1}^{2}+\theta X_{t}
$$

Where $X_{t}$ is to be the residual squared of ARMA model and $\theta$ is the term that measures the magnitude of volatility transmission across the markets. Augmented GARCH model is considered to be very versatile univariate volatility model.

This study employs one-period lagged squared returns for $X_{t}$. This is so because we could not fit AR or ARMA to any of the returns. Therefore, we report transmission of volatility of past period returns as opposed to transmission of conditional volatilities. The findings are indicated in the Table 7, 8 and 9:

Table 7: Volatility Transmission (before crisis)

\begin{tabular}{|l|}
\hline$\sigma_{t(\text { France })}^{2}=0.02+0.07 e_{t-1(\text { France })}^{2}+0.91 \sigma_{t-1(\text { France })}^{2}$ \\
\hline$\sigma_{t(\text { (Germany })}^{2}=1.40+0.12 e_{t-1(\text { Germany })}^{2}+0.55 \sigma_{t-1(\text { Germany })}^{2}-0.17 r_{t-1(U K)}^{2}$ \\
\hline$\sigma_{t(\text { traly })}^{2}=0.03+0.05 e_{t-1(\text { traly })}^{2}+0.89 \sigma_{t-1(\text { traly })}^{2}+0.05 r_{t-1(U S A)}^{2}$ \\
\hline$\sigma_{t(\text { UK })}^{2}=0.04+0.07 e_{t-1(\text { UK })}^{2}+0.84 \sigma_{t-1(U K)}^{2}+0.07 r_{t-1(U S A)}^{2}$ \\
\hline$\sigma_{t(\text { USA })}^{2}=0.01+0.03 e_{t-1(\text { USA })}^{2}+0.93 \sigma_{t-1(\text { USA })}^{2}+0.01 r_{t-1(U K)}^{2}$ \\
\hline
\end{tabular}

Table 8: Volatility Transmission (crisis)

\begin{tabular}{|c|}
\hline$\sigma_{t(\text { France })}^{2}=0.82 \sigma_{t-1 \text { (France })}^{2}+0.07 r_{t-1(\text { Germany })}^{2}+0.16 r_{t-1(U S A)}^{2}$ \\
\hline$\sigma_{t(\text { (Gemany })}^{2}=0.89 \sigma_{t-1(\text { (Germany })}^{2}+0.10 r_{t-1(\text { France })}^{2}-0.07 r_{t-1(U K)}^{2}+0.12 r_{t-1(\text { USA })}^{2}$ \\
\hline$\sigma_{t(\text { thal })}^{2}=0.85 \sigma_{t-1(t a l)}^{2}+0.18 r_{t-1(U S A)}^{2}$ \\
\hline$\sigma_{t(U K)}^{2}=0.84 \sigma_{t-1(U K)}^{2}+0.20 r_{t-1(U S A)}^{2}$ \\
\hline$\sigma_{t(U S A)}^{2}=0.86 \sigma_{t-1(U S A)}^{2}+0.10 r_{t-1(U K)}^{2}$ \\
\hline
\end{tabular}


Table 9: Volatility Transmission (after crisis)

\begin{tabular}{|c|}
\hline$\sigma_{t(\text { France })}^{2}=0.93 \sigma_{t-1(\text { France })}^{2}+0.02 r_{t-1 \text { (tally })}^{2}+0.05 r_{t-1(\text { UK })}^{2}$ \\
\hline$\sigma_{t(\text { Germany })}^{2}=0.03+0.07 e_{t-1 \text { (Germany })}^{2}+0.93 \sigma_{t-1(\text { Germany })}^{2}-0.03 r_{t-1 \text { (France })}^{2}+0.04 r_{t-1(\text { USA })}^{2}$ \\
\hline$\sigma_{t(\text { thal })}^{2}=0.05+0.06 e_{t-1(\text { thal })}^{2}+0.93 \sigma_{t-1 \text { (tally) }}^{2}$ \\
\hline$\sigma_{t(U K)}^{2}=0.04 e_{t-1(U K)}^{2}+0.93 \sigma_{t-1(U K)}^{2}+0.03 r_{t-1(U S A)}^{2}$ \\
\hline$\sigma_{t(U S A)}^{2}=0.03+0.10 e_{t-1(U S A)}^{2}+0.88 \sigma_{t-1(U S A)}^{2}$ \\
\hline
\end{tabular}

As for volatility transmissions, the analysis indicate important variations in volatility transmissions among different time periods. For example, the French market does not have volatilitly spillovers in the pre-crisis period while both German and American volatilities are transmitted during the crisis. However, post crisis Italian and British volatilities are transmitted to France. For the German market volatilities from the following markets are transmitted: UK (pre); France, UK and US (during) and France and US (post) respectively. For Italy, only US (pre and during) but no other market (post); For UK, the only volatility transmissions come from the US. This is true for all three periods under study. Finaly, the UK market is the only one that with volatility spillovers to the US market. It is important to emphasize that during the crisis, the US market volatilities are transmitted to all other markets, while the US market is affected only by volatility of the UK market. Post crisis, the only two markets not experiencing volatility spillovers from other markets are Italy and USA.

\section{Conclusions}

This paper studied the transmission of equity ETF returns and volatility among five equity markets (US and 4 major European markets) using daily data from January 2002 to March 2014. A multivariate autoregressive moving average (MARMA) model and a generalized autoregressive conditional heteroskedasticity (GARCH) model were used to identify the source and magnitude of return and volatility spillovers in three different time periods: Before 2007-2008 financial crisis, during the crisis and after the crisis. We found that there are significant co-movements among ETF returns. However, not all county specific ETF returns move in unison and a significant opportunity for portfolio diversification exists by identifying, and investing in, ETFs that do not move together. We also found that more opportunities for portfolio diversification existed before the crisis than after it. This is in line with most of the empirical studies that find increasing correlations among major equity markets after crises. 
Highest volatility before the 2007-08 crisis is exhibited by Germany and France. France also exhibits highest volatility during the crisis period followed by UK while the highest volatility after the crisis is exhibited by Italy and France. On the other hand, the US market has the lowest volatilities of all markets in all periods.

The study of volatility persistence found that in the short run, the UK market is spikey but volatilities do not persist very long. On the other hand, while short term results do not place Germany and France among the volatile markets, whatever volatility there tends to persist a long time.

We found significant volatility transmissions: during the crisis, the US market volatilities are transmitted to all other markets, while the US market is affected only by volatility of the UK market.The German market volatilies spill over to France while the German market is affected by the volatility of the UK and French markets. Post crisis, the only two markets not experiencing volatility spillovers from other markets are Italy and USA. The UK market has volatility spillovers from USA. The German market has volatility spillovers from France and USA, and the Franch market has volatility spillovers from Italy and UK. These results are in line with the findings of other studies, such as Yavas and Rezayat (2013); Kiymaz (2002 \& 2003); Majid, et al. (2009) and Kumar (2013) that find significant return and volatility spillovers in India, Brazil and S. Africa. As discussed in the introduction, higher foreign ownership rates may be responsible for magnifying spillovers since substantial declines in one market can force some investors (especially those who are highly leveraged) to sell other assests in other markets to cover their losses.

Since volatilities can proxy for risk, there are lessons for both individual and institutional investors in terms of further examining pricing securities, hedging and other trading strategies as well as framing regulatory policies. The information is also important for policymakers in the sample countries for understanding the markets' co-movements and designing policies. As hedging becomes another area of interest for investors its importance is expected to grow as a vehicle as important as asset allocation. New ETFs are created daily to be used as a hedge against a risk of market meltdown. The main idea would be to allow investors to benefit from sudden spikes in volatility while keeping the ETFs overall costs down (Economist, 2012). It is clear that innovation in both ETFs and their volatilities continue. In December 2012, iShares launched a series of new ETFs that are designed to provide exposure to equities with less risk, done by choosing stocks that have been less volatile than the overall market (Economist, 2013).

Finally, the knowledge of market co-movements and volatility transmissions during different time periods such as before, during and after financial crises could be used by various economic actors to fine-tune their investment and/or macro finance strategies. 


\section{REFERENCES}

Aloui, R.; Ben Aïssa, M.; Nguyen, D. (2011). Global financial crisis, extreme interdependences, and contagion effects: The role of economic structure? Journal of Banking and Finance, 35(1), 130-141. doi:10.1016/j.jbankfin.2010.07.021

BlackRock (2015). Exchange-Traded Funds (ETFs) I iShares - BlackRock. [online] Available at: https:// www.ishares.com/us/ [Accesses Feb 6, 2015]

Bekaert G., Hodrick, R.J., Zhang, X. (2009). International Stock Return Comovements. Journal of Finance, 64(6): 2591-2626, December. DOI: 10.1111/j.1540-6261.2009.01512.x

Bollerslev, T. (1986). Generalized Autoregressive Conditional Heteroskedasticity. Journal of Econometrics, 31(3): 307-327.

Christofi, A. \& Pericli, A (1999). Correlation in Price Changes and Volatility of Major Latin American Stock Markets. Journal of Multinational Financial Management, 9:79-93. DOI http:// dx.doi.org/10.1016/S1042-444X(98)00047-4

Dedi, L. \& Yavas, B.F. (2016). Return and Volatility spillovers in equity markets: An investigation using various GARCH methodologies. Cogent Economics \& Finance, 4(1): 1266788. DOI http://dx.doi.org/10.1080/23322039.2016.1266788

Diebold, F.X. and Yilmaz, K. (2011). Equity Market Spillovers in the Americas, in R. Alfaro (ed.) Financial Stability, Monetary Policy, and Central Banking. Santiago: Bank of Chile Central Banking Series, Volume 15, 199-214.

Duan, J. C. (1997). Augmented GARCH (p, q) Process and its Diffusion Limit. Journal of Econometrics 79: 97-127.

Dungey, M.; Martin, V. (2007). Unravelling financial market linkages during crises. Journal of Applied Econometrics, 22(1): 89-119.

Engle, R F. (1982). Autoregressive Conditional Heteroskedasticity with Estimates of the Variance of United Kingdom Inflation. Econometrica 50:987-1007.

Exchange traded funds: from vanilla to rocky road (2012, Feb 25-March 2), in special report:financial innovation, Economist. Retrieved March 21, 2015. Available at: http://www.economist.com/ node/21547989

Exchange traded funds: 20 years young, (2013, Jan. 26-Feb. 1), Economist. Retrived 18 March 2015. Available at: http://www.economist.com/news/finance-and-economics/21570711-anniversary-successful-financial-innovation-twenty-years-young

Gray, D. (2009). Financial contagion among members of the EU-8: a cointegration and Granger causality approach. International Journal of Emerging Markets, 4(4): 299-314. DOI http://dx.doi. org/10.1108/17468800910991214

Grosvenor, T., Greenidge, K. (2012). Stock maket volatility spillover from developed markets to regional markets. Journal of Business, Finance and Economics in Emerging Economies, 7(2): 43-61 http://www.ccmf-uwi.org/node/1679

Hamao, Y., Masulis, R. W., and Ng, V. (1990). Correlations in Price Changes and Volatility across International Stock Markets. The Review of Financial Studies, 3 (2): 281-307.

Kenourgiosa, D., Samitasb, A., Paltalidisc N. (2011). Financial crises and stock market contagion in a multivariate time-varying asymmetric framework. Journal of International Financial Markets, Institutions and Money, 21(1): 92-106. DOI http://dx.doi.org/10.1016/j.intfin.2010.08.005

Kim, S. W., and Langrin, R. B (1996). Stock Price Movements Spillovers under Foreign Exchange Liberalization: The Case of Jamaica, Trinidad and Tobago, and the United States. University of the West Indies, Mona, Jamaica. Presented at the XXVIIth Annual Conference on Monetary Studies. 
Kiymaz, H. (2002). An analysis of linkages among equity markets: study of selected Latin American and Developed countries. Journal of Economics and Business Studies,1(1): 16-33.

Kiymaz, H. (2003). Are there diversification benefits from investing in frontier equity markets? Journal of Accounting and Finance Research, 11(2): 64-75.

Kumar, K. K., and Mukhopadyay, C. (2002). A Case of Us and India. NSE Research Paper. Available at www. nseindia. com

Kumar, M. (2013). Returns and volatility spillover between stock prices and exchange rates: Empirical evidence from IBSA countries. International Journal of Emerging Markets, 8 (2) p108 - 128. DOI http://dx.doi.org/10.1108/17468801311306984

Li, H. (2007). International Linkages of the Chinese Stock Exchanges: A Multivariate GARCH Analysis. Applied Financial Economics, 17: 285-295.

Majid, M.S.A., Meera, A.K.M., Omar, M.A. and Aziz, H.A. (2009). Dynamic linkages among ASEAN-5 emerging stock markets. International Journal of Emerging Markets, 4 (2): 160-84. DOI http://dx.doi.org/10.1108/17468800910945783

Makridakis, S. G., Wheelwright, S., and Hyndman, R. (1998). Forecasting Methods and Applications, 3rd Ed. Wiley: Hoboken, New Jersey.

Money and Investments (2016, March 28), Wall Street Journal, Section C page C6.

Not passing the buck: Global capital flows have slowed down, (2016, December 17-25), Economist, Retrieved 18 December 2016.

Orlowski, L.T (2012). Financial crisis and extreme market risks: Evidence from Europe. Review of Financial Economics, 21(3):120-130. http://dx.doi.org/10.1016/j.rfe.2012.06.006

Rey, H. (2013). Dilemma not Trilemma: The Global Financial Cycle and Monetary Policy Independence. Available at: www.kc.frb.org/publicat/sympos/2013/2013Rey.pdf

Rezayat, F. and Yavas, B.F. (2006). International Portfolio Diversification: A Study of Linkages among the U.S., European and Japanese Equity Markets. Journal of Multinational Financial Management, 16: 440-458. DOI http://dx.doi.org/10.1016/j.mulfin.2005.10.002

Scheicher, M. (2001). The Co-movements of Stock Markets in Hungary, Poland and the Czech Republic. International Journal of Finance and Economics, 6: 27-39. DOI: 10.1002/ijfe.141

Slimane, F.B; Mehanaoui, M, and Akbar Kazi, I. (2013). How Does the Financial Crisis Affect Volatility Behavior and Transmission among European Stock Markets? International Journal of. Financial Studies.1 (3): 81-101. doi:10.3390/ijfs1030081

Syllignakis, M.N; Kouretas, G.P. (2011). Dynamic correlation analysis of financial contagion: Evidence from the central and eastern European markets. International Review of Economics and Finance, 20(4): 717-732. DOI http://dx.doi.org/10.1016/j.iref.2011.01.006

Yavas, B.F and Rezayat, F.(2008). Integration among Global Equity Markets: Portfolio Diversification using Exchange-Traded Funds. Investment Management \& Financial Innovations. 5(3):3043.

Yavas, B.F and Rezayat, F (2013). Market Volatility: A Study of Equity Markets of US, Canada, Germany and China. Journal of International Finance and Economics. 13(4):107-122. DOI: http://dx.doi.org/10.18374/JIFE-13-4.12

Yavas, B.F and L. Dedi (2016). An investigation of return and volatility linkages among equity markets: A study of selected European and emerging countries“, Research in International Business and Finance 37, 583-596, ISSN: 0275-5319 http://dx.doi.org/10.1016/j.ribaf.2016.01.025 